\title{
The Relationship of Adding Allicin Powder to Diet on Concentration of Glutathione Enzyme and Histological of Thymus Gland of Broiler
}

\author{
Salman K.A.A. ${ }^{1}$, Al-Mashhadani H.A. ${ }^{2}$, Al-Hayani W.KH ${ }^{2}$ \\ ${ }^{1}$ Assistant Prof., ${ }^{2}$ Prof., Department of Animal Production, College of Agricultural Engineering Science, \\ University of Baghdad, Iraq
}

\begin{abstract}
This study was conducted at the field of poultry - Abu Gharib/department of Animal Production/college of agricultural engineering Sciences - university of Baghdad, during the period from 12/10/2019 to 24/11/2019 duration (42 days), to demonstrate the effect of adding different levels of Allicin to broiler diet on Glutathione level in blood and histological of thymus gland, total of 225 Ross 308 chicks was used. Birds were randomly distributed into five treatment groups which were : First treatment T1: without additives to diet (control), other treatments T2, T3, T4, T5 was added Allicin at a rate of $(800,600,400,200 \mathrm{mg} / \mathrm{Kg}$ diet $)$ respectively, and Allicin was added from first day until the end of the experiment for all addition treatments, results of this experiment showed: High significant $(\mathrm{P}<0.01)$ in all additive treatments compared to control for glutathione enzyme in plasma at 21, 42 days for broiler age. With respect to the histological examination of thymus gland showed that adrenocortical hyper function and degeneration and depletion in lymphoid tissue in T2, T3 and T5 treatments compared to control treatment, while cortex and Pulp with a lymphatic interstitial in the stage of degeneration for $\mathrm{T} 4$ and control treatments.
\end{abstract}

Keyword: Allicin, glutathione, thymus gland, broiler.

\section{Introduction}

Herbs were used as natural and safe food supplements in poultry diets as a tool to increase animal production efficiency in general and improve the health and production of poultry in particular ${ }^{(1)}$, a biological characteristics were attributed to Allindailylsulphide and Allicin, Allicin is naturally produced from the breakdown of garlic tissue with the presence of alliinase ${ }^{(2)}$, which is belongs to the Alliaceae famil( ${ }^{(3)}$, Allicin has anti-bacterial, anti-fungal, and anti-inflammatory properties. $^{(4),(5,6)}$ Explain the primary mechanics of Allicin's anti-oxidant and anti-stress activity by trapping free radicals when the Allicin decays, it forms 2-Propene sulfuric acid and this compound is the one that binds to free radical. It interprets it as an antioxidant and anti-stress, and reduces oxidative stress ${ }^{(7,8)}$, Thus, it has a stimulating effect of immunity ${ }^{(9)}$, Alliin is the main source of Allicin, a non-protein amino acid, and $\mathrm{s}+$ allylcysteinesulfoxides are hydrolyzed by enzymes alliinase Upon the interaction of Alliin, it leads to the production of Dehydroalanine, the allylsufffenic acid, and two of these acids are self-condensing to produce one molecule of Allicin ${ }^{(10)}$. It is worth noting that the alternative pathway to the formation of Allicin is from glutathione after obtaining the allele group and then it enters a chain of reactions ${ }^{(11)}$, glutathione is one of the most important antioxidants in the body due to its presence inside the cell and the body can manufacture it from amino acids ${ }^{(12)}$, and glutathione scavenging free radicals $^{(13)}$, it also has a role in the metabolism process and the regulation of cellular activities and regulate the immune response $\mathrm{e}^{(14,15)}$, it also has a metabolic function that includes cysteine storage ${ }^{(16)}$. The immunity of the body has been connected to activities associated to the lymphomyeloid organs and their cells, the lymphatic system is compounded by a network of diffuse defense, birds have discrete lymphoid tissues and absence of lymph nodes ${ }^{(17)}$, and thymus gland is ranked as one of the primary lymphoid organs, it's the first organ which formed and grows instantly after birth in response to postnatal antigen stimulation and the demand for great number of mature $\mathrm{T}$ cells ${ }^{(18)}$, in other hand thymus may 
function as a secondary lymphoid organ because it is capable of playing a direct role in the immune reactions, and the appearance of plasma cells in chicken thymus at different ages provides further support to this idea. This is a vital role in vaccination of chicken ${ }^{(19)}$. It considered as the initial site for development of $\mathrm{T}$ cell immunological function also it generate, differentiate and mature $\mathrm{T}$ and $\mathrm{B}$ lymphocytes respectively $(20,21)$. So the aim of this study came to know the effect of using different levels of garlic- Allicin on the concentration of glutathione enzyme and histological sections of the thymus gland in broilers.

\section{Materials and Method}

Birds and Dietary treatment: Allicin was added from first day until the end of the experiment for all addition treatments, all treatments gave ad libitum diet and water in all the experiment period and diet contents chosen as a ${ }^{(22)}$ which contain protein $23 \%$ in initiator diet and $21.5 \%$ in growth diet and $22 \%$ in final diet, while metabolism energy was 3000.5, 3103.7 and 3204.6 $\mathrm{Kcal} / \mathrm{kg}$ diet for each diet.

Soybean cake used an Argentine source of crude protein content by $48 \%$ and $2440 \mathrm{Kcal} / \mathrm{Kg}$ metabolism energy, protein meal user product from Netherlands origin)Brocon(contain $40 \%$ crude protein $0.2107 \mathrm{kcal} /$ $\mathrm{kg}$ protein metabolism energy, $0.5 \%$ crude fat $2.20 \%$ crude fiber $5 \%$, calcium $4.68 \%$, phosphorus $3.85 \%$ lysine $4.12 \%$, methionine $4.12 \%$, methionine plus cysteine $0.42 \%$, tryptophan $0.38 \%$, threonine $1.70 \%$. it contains a mixture of vitamins and minerals needed believes rare birds of these elements..

Allicin Chemical Analysis: Chemical analysis (infrared spectroscopy of Allicin) was carried out for the purpose of accurate diagnosis of Allicin and knowledge of its effective groups when using Fourier-transform infrared spectroscopy (FTIR) to measure infrared radiation within the range $\left(4000-6000 \mathrm{~cm}^{-1}\right)$ using $\mathrm{K} \mathrm{Br}$ tablet for the solid material in the Ibn Sina Laboratory/ College of Girls Education/University of Baghdad (23), the results of this analysis showed that Allicin powder was pure.

GSH Standards Solution (0.001M): Stock standards solution $(0.001 \mathrm{M})$ was prepared by dissolving (0.0156) $\mathrm{g}$ of GSH in a final volume of $50 \mathrm{ml}$ of $(0.02 \mathrm{M})$ EDTA solution. Dilution were made in EDTA Solution to $(5,10,15,20,30,40,50 \mu \mathrm{m} / \mathrm{mL}$ ), (This working standard solution should be prepared daily).
Procedure: Serum Glutathione was determined by using a modified procedure using Ellman's reagent (DTNB), which is summarized as follows: Duplicate of each standard and sample test tube were prepared solution were mixed tubes were mixed in a vortex mixer, the spectrophotometer was adjusted with reagent blank to read zero absorbance (A) at $412 \mathrm{~nm}$ and the absorbance of standard and sample are read within 3 minutes of the addition of DTNB reagent. The concentration of serum glutathione was obtained from the calibration curve in $\mu \mathrm{M} / \mathrm{mL}^{(24,25)}$.

Histological traits: Random samples of broiler meat were slaughtered at the end of the experiment at the age of 42 weeks and 6 samples of thymus gland were preserved for each treatment in formalin solution $10 \%$ concentration until the tissue sections were performed, as part of the gland was cut and made covered by a thin layer of wax after this was applied with formalin for 24 hours, after which the passage was passed in different concentrations of alcohol $60,70,80$ and $90 \% \%$ For a quarter of an hour in each concentration after which it is placed in the wax mold at a temperature of $50{ }^{\circ} \mathrm{C}$ for 24 hours, then the mold is placed in freezing for 24 hours after it is placed in the Microtom device as this device cuts the mold into slices and then fix the slices on glass slides and is placed In an oven at $20^{\circ} \mathrm{C}$ for one hour after which we wash it with distilled water after the slices are stained with hemotoxin and eosin tincture (haemaloxylin and eosin) Then the slice is passed in different concentrations of Xylol 70, 80 and $90 \%$. Then it is passed in different concentrations of alcohol 60, 70, 80 and $90 \%$. After this process, the lid is placed over the slice and the slice is placed in the oven for one hour to be dried after so the slides are examined microscopically to see the effect ${ }^{(26)}$.

\section{Results and Discussion}

Table (1) showed a High significant $(\mathrm{P}<0.01)$ in all additive treatments compared to control for glutathione in plasma at 21, 42 days of broiler age. The reason for the increase in the concentration of glutathione in the addition of Allicin may be due to the role of Allicin as an antioxidant by trapping free radicals when the Allicin decomposes as it forms acid 2-propenesuifenic it is this compound that binds to free radicals and reduces oxidative stress $^{(9)}$. It is worth noting that the alternative pathway to the formation of Allicin is from glutathione after obtaining the allele group and then it enters a chain of reactions ${ }^{(11)}$. So, through these points, the results of 
this research indicated the role of Allicin in preventing reactive oxygen types by regulating the removal of enzymes and toxins because the reactive oxygen type (ROS) is extremely harmful to the cell by oxidizing fats and proteins, and since the glutathione is low in cell. .

Table 1. Effect of adding Allicin on Glutathione enzyme at $21 \& 42$ days of age (Mean \pm Standard error)

\begin{tabular}{|c|c|c|}
\hline Treatments & $\begin{array}{l}\text { Glutathione at } \\
21 \text { days of age }\end{array}$ & $\begin{array}{l}\text { Glutathione at } \\
42 \text { days of age }\end{array}$ \\
\hline $\mathrm{T} 1$ & $22.05 \pm 0.25 \mathrm{~d}$ & $23.62 \pm 0.04 d$ \\
\hline $\mathrm{T} 2$ & $25.65 \pm 0.25 \mathrm{c}$ & $25.78 \pm 0.15 b$ \\
\hline T3 & $27.95 \pm 0.45 b$ & $26.49 \pm 0.04 \mathrm{a}$ \\
\hline $\mathrm{T} 3$ & $30.85 \pm 0.65 a$ & $25.56 \pm 0.05 b$ \\
\hline T5 & $29.50 \pm 0.20 \mathrm{a}$ & $24.69 \pm 0.02 \mathrm{c}$ \\
\hline Significant & $* *$ & $* *$ \\
\hline
\end{tabular}

Means having with the different letters in same column differed significantly** $(\mathrm{P}<0.01)$
It is the most important part that provides protection against ROS by forming glutathione ${ }^{(27,28)}$. This result is consistent with his finding ${ }^{(29)}$ activity of glutathione because Allicin could enhance antioxidants and thus detoxify the liver cells in Rat.

The histological examination of thymus gland showed that adrenocortical hyper function and degeneration and depletion in lymphoid tissue in T2, T3 and $\mathrm{T} 5$ treatments compared to control treatment, while cortex and Pulp with a lymphatic interstitial in the stage of degeneration for T4 and control treatments. Showed in figure (1, 2, 3, 4 and 5).

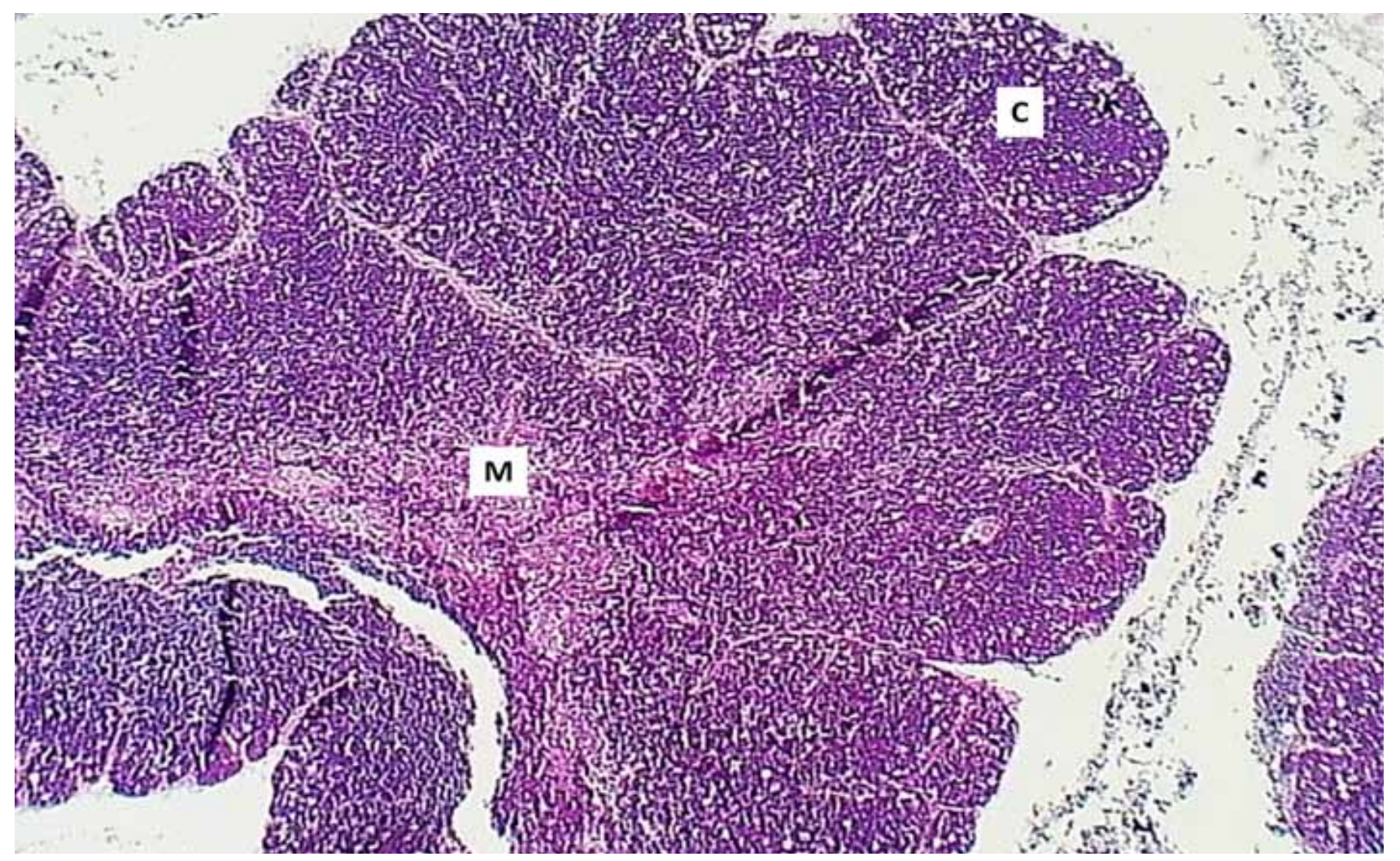

Figure 1. Histological section of the thymus gland (control group) shows: cortex (C), pulp (M). Tincture of Yamatoxin and Eosin. X40 


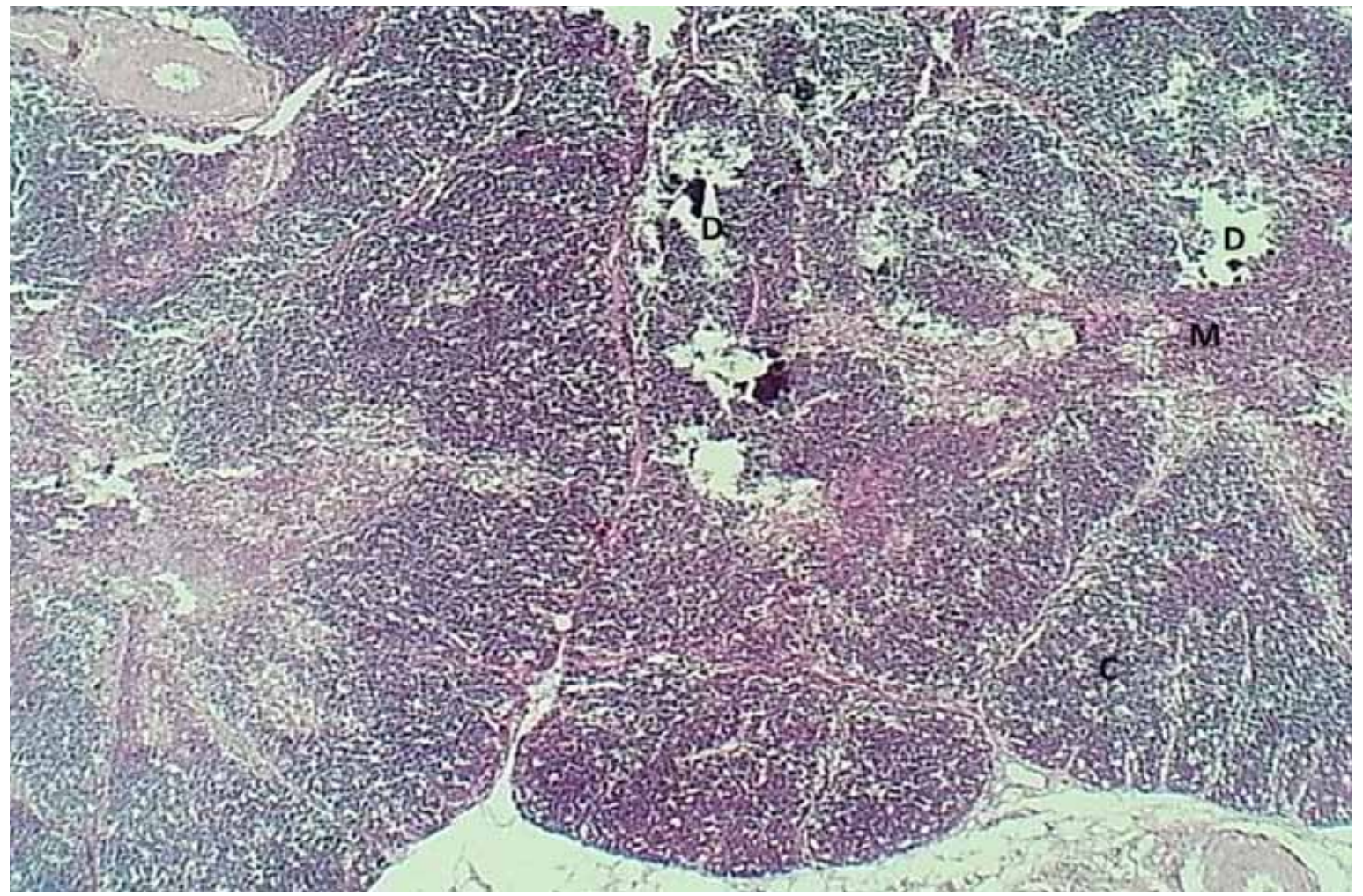

Figure 2. Histological section of the thymus gland (group II) shows: Adrenocortical hyper function (C), while the pulp region (M) Degeneration and depletion in lymphoid tissue (D) is a dye of amatoxylin and eosin. X40

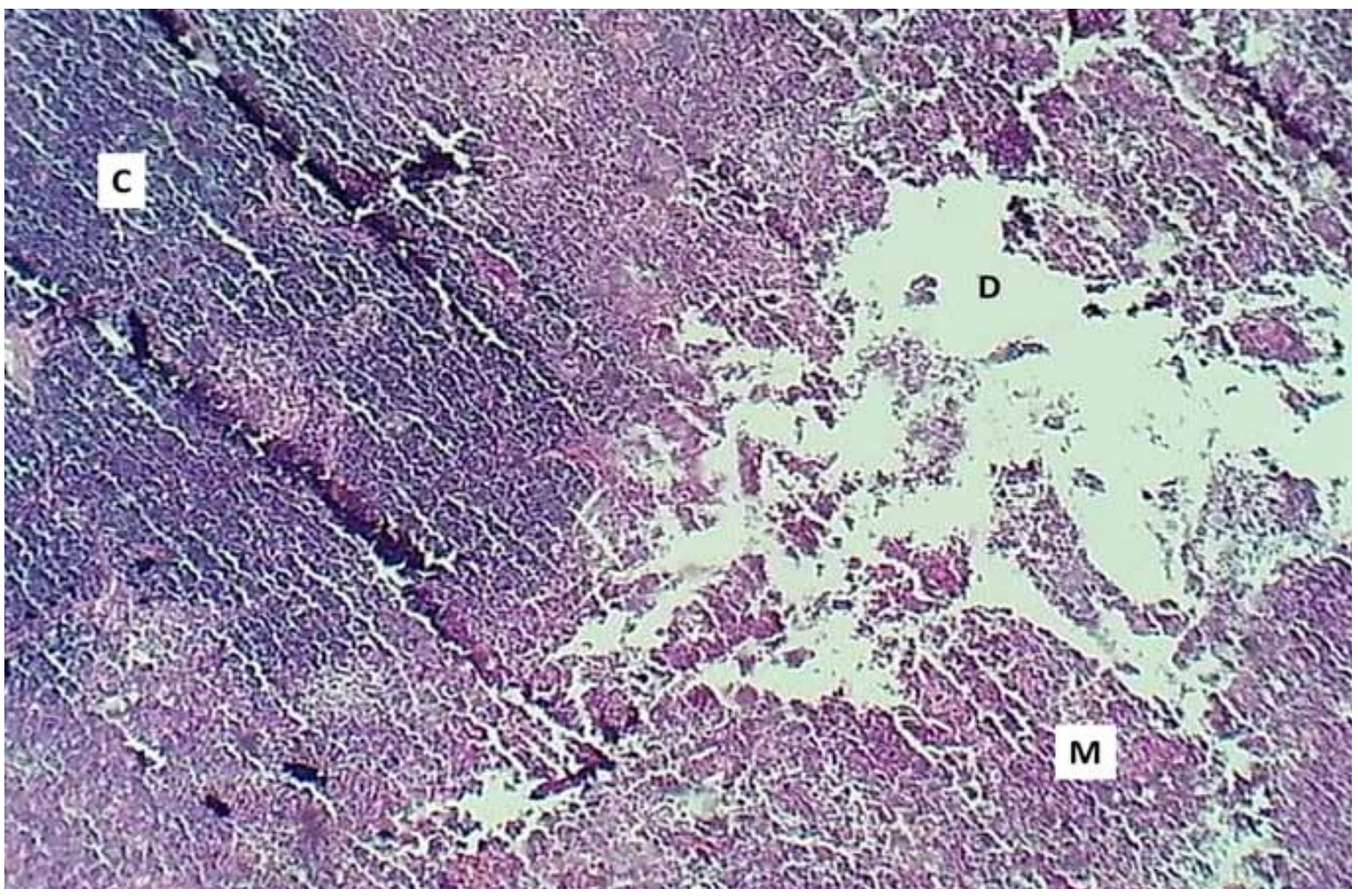

Figure 3. Histological section of the thymus gland (group III) shows: Adrenocortical hyper function (C), while the pulp region (M) Degeneration and depletion in lymphoid tissue (D) is a dye of amatoxylin and eosin. X40 

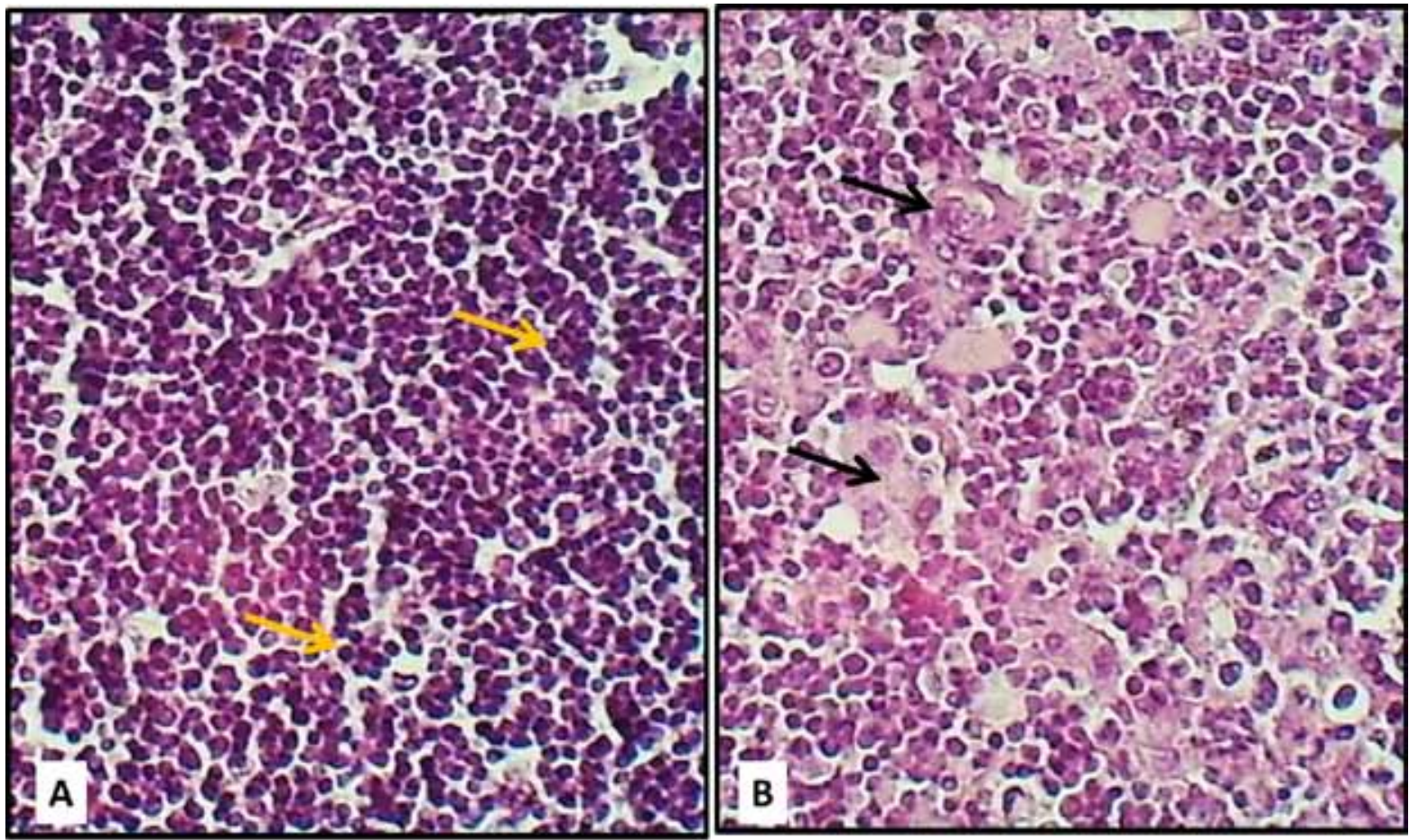

Figure 4. Thyroid tissue enlarged cross section (group IV). Figure A shows the natural appearance of lymphocyte groups in the cortex (yellow arrow). Figure (B) shows the normal appearance of lymphocytes in the phase of degeneration (black arrows). Tincture of Yamatoxin and Eosin. X400
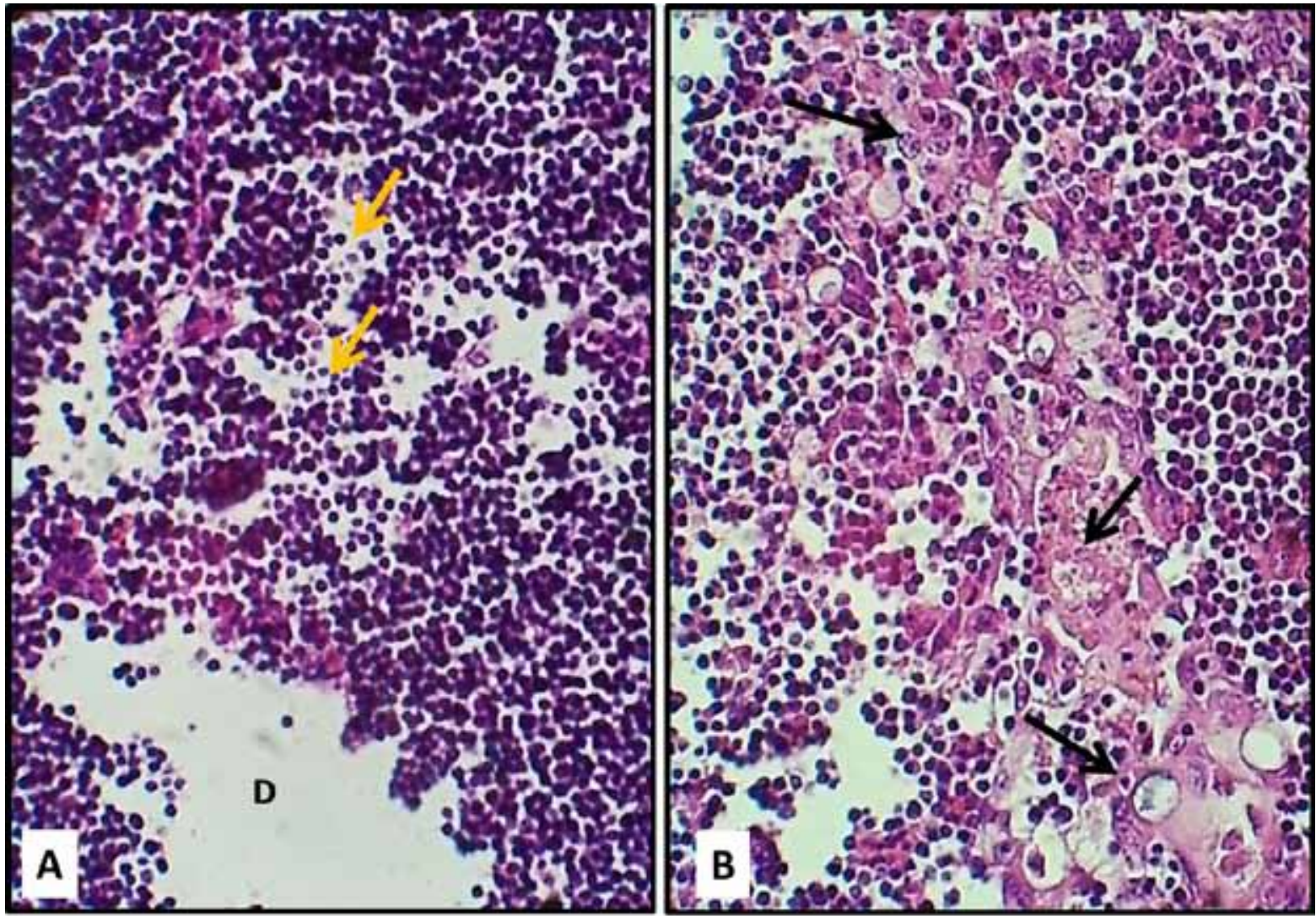

Figure 5. A tissue enlarged section of the thymus gland (group V). Figure A shows lymphocyte degeneration of the cortex (yellow arrow) with tissue depletion (D). (B) Stages of Degeneration and depletion in lymphoid cells (black arrows). Tincture of Yamatoxin and Eosin. X400 
Additionally, with regard to the tissue sections of the thymus gland, these results may be attributed to the use of Allicin at concentrations that may be high because degeneration and depletion in lymphoid tissue it occurs when there is an actual chemical change in the lymphoid tissue itself .And also Enlargement of the cortex and pulp (Pumpkin).Gland disorders are conditions that interfere with the normal functioning of the gland ${ }^{(30,31)}$.

\section{Conclusion}

The present study concluded that the use of Allicin at these mentioned levels has led to an increase in the concentration of glutathione enzyme Which in turn is considered a powerful antioxidant to protect the cell from damage that might be caused by free radicals additionally, Allicin levels may have led to Degeneration and depletion in lymphoid tissue and Enlargement of the cortex and pulp (Pumpkin) Thus, allicin levels can be reduced to maintain thymus tissue.

\section{Conflict of Interest: None}

\section{Funding: Self}

Ethical Clearance: Not required

\section{References}

1. Kostadinovic, L.J. Herbs and animal health. Monogrph University of Novi Sad, Institute for food Technology, Novi Sad, Serbia, 2013. 1: 1-86.

2. Stoll, A. and seebeck, E. Alliin, die genuine mutter sustains des knoblauchols. Subacuteruminal acidosis in dairy herds: Areview. Animal feed Helv. Chim, Acta1948., 31: 189-210.

3. Gabor, S., Vilmos, P., Bela, N., Istvanne, E. and Gyorgyet, N. New type of immune-stimulant to increase antibody production in response to viral and bacterial vaccines. Magyar Allatorvosok Lapja, 1998. 120:719-721.

4. Bautista, D.M., Movahed, P., Hinman, A., Axelsson, H.E., Sterner, O., Hogestatt, E.D., Julius, D., Jordt, S.E. and Zygmunt, P.M. Pungent products from garlic activate the sensory ion channel TRPA1. Proc Natl Acad Sci USA 2005. 102 (34): 1224852.

5. Block, E, Dane, A.J., Thomas, S. and Cody, R.B. Applications of Direct Analysisin Real Time-Mass Spectrometry (DART-MS) in Allium Chemistry. Propenesulfenic and 2-Propenesulfinic Acids,
Diallyl Trisulfane S-Oxide and Other Reactive Sulfur Compounds from Crushed Garlic and Other Alliums. Journal of Agricultural and Food Chemistry 2010. 58 (8): 4617-25.

6. Vaidya, V., Ingold, K.U. and Pratt, D.A. Garlic source of the ultimate antioxidant- sulfenic acids. Angew. Chem. Int. Ed. Engl., 2009. 48: 157 - 160.

7. Lindsey, J., Bernhard, H., Geierstanger, V., Viswanath, M., Samer, R., Eid, S. and Ardem, P. Thepungency of garlic: Activation of TRPA1 and TRPV1 in response to allicin]". Current Biology 2005. 15 (10): 929-934.

8. Choudhary, R. Benificial Effect of Allium Sativum and Allium Tuberosumon Experimental Hyperlipidemia and Atherosclerosis. Pak. J. Physiol 2008:. 4, 7-9.

9. Cho, S,j., Rhee, D,k. and Pyo, S. Allicin, a major component of garlic, inhibits apoptosis of macrophage in a depleted nutritional state. Nutrition 2006. . 22(11-12):1177-84.

10- Ilic, D., Nikolic, V., Nikolic, L. Stankovic, M., Stanojevic, L. and Cakie,M.. Aliccin and related compounds Biosynthesis, synthesis and pharmacological activity. Facta Univ. Phys. Chem. Technol., 2011 9: 9-20.

11. Borlinghaus, J., Albrech, F., Gruhlke, M.C.M., Nwachukwn, I.D. and Slusarenko, A.J. Allicin: Chemistry and Biological properties. J .molecules 2014., 19:12591-12618.

12. Traverso,N.R., Ricciarelli, M., Nitti,B., Marengo, A.L., Furfaro,M.A., Pronzato and Domenicotti C. Role of glutathione in cancer progression and chemoresistance. Oxidative medicine and cellular longevity. 2013.

13. Bains,J.S. and Shaw, C.A. Neurodegerative disorders in humans: the role of glutathione in oxidative stress-mediated neuronal death. Brain Research Review 1997., 253: 335-358.

14. Klatt, P. and Lamas, S. Regulation of protein function by s- glutathione in response to oxidative and nitrosative stress. European Journal of biochemistry, 2000. 2671: 4928- 4944.

15. Wu,G.Y. Z., Fang,S.,Yang,J.R., Lupton and Tuner,N.D. Glutathione metabolism and its implications for health. The Journal of nutrition 2004., 1343: 489-492.

16. Meister,A. Glutation mrtabolism and its selective modification. Journal of biological chemistry, 
1988. 26333: 17205- 17208.

17. Rose, E. The immune system in birds. Journal of the Royal Society of Medicine, 1979. 72, (9):701705.

18. Suster, S. and Rosai, J. Thymus. In Histology for Pathologists (S. Sternberg, Ed.) Raven Press, New York: 1992. 261-75.

19. TreeshS.A.,A.O.BukerandN.S.Khair.Histological, histochemical and immunohistochemical studies on thymus of chicken. International Journal of Histology and Cytology 2014. 1(11): 103-111.

20. Haley, P. J. Species differences in the structure and function of the immune system. Toxicology, 2003. 188: 49- 71 .

21. Hui, S., Kemei, P., Shenghe, L.I., Yan, W., Lan, W. Morphological characterization of the immune organs in ostrich chicks. Turk. J. Vet. Anim. Sci. 2012. 36(2): 89-100.

22. National Research Council. Nutrient Requirements of poultry $.9^{\text {th }}$.rev. ed. National Academy Press. Washington, D C.USA. 1994.

23. Lambert, J. B. Organic structural analysis. Macmillan Pub Co1976. .

24. Burtis, C.A. and Ashwood, E.R. Text Book of clinical chemistry $.3^{\text {rd }}$ ed . Philadelphia WB SUNDERS. 1999.

25. Rahman, I. Kode, A. and Biswas, S.K. Assay for quantitative determination of glutathione and glutathione disulfide levels using enzymatic recycling method. Nat Protocol.; 2006. 1(6):315965.

26. Luna, L.G. Manual of Histological staining Method of Armed force institute of Pathology, $3^{\text {rd }} \mathrm{Ed}$ McGraw Hill Book Company. New York. 1968.

27. Bergamini, C.M., Gambetti, S., Dondi, A. and Cervellati, C. Oxygen, reactive oxygen species and tissue damage. Curr. Pharm. Des 2004. 10:16111626.

28. Dickinson, D.A. and Forman, H.J. Glutathione in defense and signaling- lessons from a small Thiol. Ann. N.Y Acad. Sci., 2002. 973:488-504.

29. Chih-Chung, W.u, Yung-Lin, Chu. and LeeYan Sheen. Allicin modulates the Antioxidation and Detoxification Capabilities of Primary Rat Hepatocytes. Journal of Traditional and Complementary Medicine, 2014. 2, 4, pp. 323-330.

30. Cooper, M.D., Raymond, M.D., Peterson, D.A., Mary Ann South, M.D. and Robert, A.G. The function of the thymus system and the bursa system in the chicken. From the pediatric research laboratories of the variety club heart hospital, University of Minnesota: 1965. 11-14.

31. Tarek, K., Mohamed, M., Omar, B. and Hassina, B. Morpho-Histological study of the thymus of broiler chickens during post hashing age. Int. J. of poultry Sci 2012, 11:78-80. 